\title{
Identification of Fecal Sex Steroid Metabolites and Evaluation of Ovarian Cycle and Pregnancy in Somali Wild Ass (Equus africanus somaliensis)
}

\author{
Muren $^{1)}$, Satoshi KUSUDA ${ }^{1,2) *}$, Eri SHIBATA ${ }^{3)}$ and Osamu DOI ${ }^{1,2)}$ \\ 1) The Graduate School of Agricultural Science, Gifu University, 1-1 Yanagido, Gifu 501-1193, Japan \\ 2) Faculty of Applied Biological Sciences, Gifu University, 1-1 Yanagido, Gifu 501-1193, Japan \\ 3) Kanazawa Zoological Garden of Yokohama, 5-15-1 Kamariyahigashi, Kanazawa-ku, Yokohama 236-0042, Japan
}

[Received 30 December 2013; accepted 22 April 2014]

\begin{abstract}
This study aimed to establish a noninvasive method for monitoring reproductive endocrinology in a female Somali wild ass (Equus africanus somaliensis). Enzyme immunoassays (EIA) using progesterone $\left(\mathrm{P}_{4}\right)$, estradiol-17 $\beta\left(\mathrm{E}_{2}\right)$ and estrone $\left(E_{1}\right)$ antisera were used to analyze fecal progestagens and estrogens. Then, fecal steroid metabolites of different pregnancy stages were identified by a combination of high performance liquid chromatography (HPLC) and EIA. The change in fecal progestagens showed ovarian cyclicity, but estrogens showed no distinct changes during non-pregnancy. Based on the profile of progestagen concentration, it was calculated that an average $( \pm \mathrm{SD})$ ovarian cycle was $22.7 \pm$ 2.9 days. Fecal progestagen levels were fluctuated throughout the pregnancy, sharply increasing on the 67th and 347th days of pregnancy, and the maximum concentration occurred just before parturition (stillbirth). The estimated gestation period by the progestagen profile was 390 days. Estrogen levels also sharply increased from the 95th day of pregnancy, reached a peak in the middle of pregnancy, and then gradually decreased until approaching parturition (stillbirth). 5 $\alpha$-Pregnane-3 $\beta$-ol-20-one, $5 \alpha$-pregnan-3, 20-dione, $\mathrm{E}_{2}$ and $\mathrm{E}_{1}$ were mainly detected in feces throughout the pregnancy. The results indicated that the excretion pattern of $5 \alpha$-pregnane-3 $\beta$-ol-20-one and $5 \alpha$-pregnan-3,20-dione detected in feces is effective for monitoring the ovarian cycle and pregnancy, and the profiles of fecal $E_{2}$ and $E_{1}$ reflect the endocrine function of fetoplacental units.
\end{abstract}

Key words: estrous cycle, fecal hormone, progesterone, pregnancy, Somali wild ass

— Jpn. J. Zoo. Wildl. Med. 19(2) : 49-56, 2014

\section{INTRODUCTION}

The Somali wild ass (Equus africanus somaliensis) is a subspecies of the African wild ass and is found in the Eritrea, Ethiopia, and Somalia [1]. The number of Somali wild asses has been decreasing rapidly because it is hunted for food or medicinal purposes and is in competition with livestock [2]. The total number of observed Somali wild asses in Eritrea and Ethiopia is 70; there may be as many as 600 in these two countries, but this number is a very rough extrapolation from

\footnotetext{
* Corresponding author :

Satoshi KUSUDA (E-mail: kusuda@gifu-u.ac.jp)
}

more intensely studied areas [2]. The extinction of Somali wild ass is a high probability [1, 2]. By 2013, the captive population numbered 220 [3]. For a captive breeding program of the species, studying the reproductive status of Somali wild ass to increase their population seems urgently necessary.

In previous reports, transrectal ultrasonography and assay of blood hormones were applied for reproductive status monitoring in female domestic asses [4-7]. However, using this method for wild ass is potentially dangerous for humans. Fecal steroid metabolite analysis to monitor the reproductive status is noninvasive and has been widely used for zoo and wildlife species [8]. Intravenously infused ${ }^{14} \mathrm{C}$-progesterone $\left(\mathrm{P}_{4}\right)$ was mainly (75\%) excreted in the feces of ponies [9]. It is also reported that fecal progestagen assays are suitable for 
noninvasive monitoring of the estrous cycle in domestic mares (E. caballus) and Przewalski mares (E. przewalskii) [10]. Fecal progestagens and estrogens were used to monitor ovarian cycles, and to diagnose and monitor pregnancy in Grevy's zebra (E. grevyi) [11]. Up to now, fecal steroid metabolite analysis has not been described for wild asses.

This study aimed to establish a noninvasive monitoring method for evaluating the reproductive status in Somali wild ass, to characterize the overall pattern of fecal hormones for diagnosing / monitoring the ovarian cycle and pregnancy, and to identify the components of fecal hormones in different pregnancy stages.

\section{MATERIALS AND METHODS}

\section{Animal and sample collection}

The female Somali wild ass (born on 1 August, 2001) used in this study was kept with a male ass at Kanazawa Zoological Gardens in Yokohama, Japan. Fresh-like feces were collected from the floor of the housing pen in the morning one to three times a week from June, 2007 to October, 2009. Fecal samples were placed in a Ziploc bag and stored at $-20^{\circ} \mathrm{C}$ immediately after collection.

Two pregnancies during this study period resulted in death just after birth (first, 1 February, 2008) and stillbirth (second, 10 July, 2009). Both of the foals were male and weighed $27.65 \mathrm{~kg}$ and $31.00 \mathrm{~kg}$, respectively.

\section{Fecal steroid assay}

Approximately $30 \mathrm{~g}$ frozen feces were thermally dried for approximately $3 \mathrm{~h}$. The dried fecal steroids were extracted according to a previous report [12]. Briefly, $5 \mathrm{ml}$ of $80 \%$ methanol was added to $0.1 \mathrm{~g}$ fecal powder and vortex-mixed for $30 \mathrm{~min}$. After centrifugation at 2,500 rpm for $10 \mathrm{~min}, 100$ $\mu 1$ supernatant methanol fraction was diluted at a ratio of 1:100 with assay buffer (0.04 M disodium hydrogen phosphate dihydrate buffer containing $0.1 \%$ bovine serum albumin in $0.15 \mathrm{M}$ sodium chloride). Fecal samples assay was determined by enzyme immunoassay (EIA) with $\mathrm{P}_{4}$ (LC-28; Aska Pharma Medical, Kanagawa, Japan), estradiol-17 $\beta$ ( $\left.\mathrm{E}_{2}\right)$ (FKA 236-E; Cosmo Bio, Tokyo, Japan) and estrone ( $\left.\mathrm{E}_{1}\right)$ (FKA 234-E; Cosmo Bio) antisera. The main cross-reactivities of these 3 antisera have been shown in previous reports [12, 13].

\section{High performance liquid chromatography (HPLC)}

To investigate the changes in the components of fecal progestagen and estrogen metabolites during pregnancy, these metabolites were analyzed by a combination of HPLC and EIA using each pooled extraction liquid of feces during early [1130 days (EP): first half 1-67 days (FEP); second half 68-130 days (SEP)], mid- (131-260 days, MP), and late (261-390 days, LP) pregnancy in a female Somali wild ass. Prior to HPLC, $5 \mathrm{ml}$ of $80 \%$ methanol extract of feces was collected during each pregnancy stage. After mixing the $5 \mathrm{ml}$ extraction liquid and 35 $\mathrm{ml}$ assay buffer, the whole extract was passed through a SepPak C-18 column (Sep-Pak plus C-18 Environmental Cartridges; Waters, Milford, MA, USA) and steroids were eluted with $5 \mathrm{ml}$ $100 \%$ methanol. After completely vaporizing $5 \mathrm{ml}$ extract in a water bath at $100^{\circ} \mathrm{C}$, it was dissolved in $1 \mathrm{ml}$ assay buffer and then extracted by diethyl ether extraction procedures. Finally, it was dissolved in $0.5 \mathrm{ml}$ of $100 \%$ methanol and used as the sample for measurement. HPLC separation of progestagen and estrogen metabolites was carried out by the method used in a previous report [13]. Progestagens and estrogens were separated using a reverse-phase Nova-Pak C-18 column $(3.9 \times 30.0 \mathrm{~mm}$; Waters $)$, and dissolved in a mixed solution of acetonitrile (ACN/water; 40/60, v/v). An extract sample of $20 \mu \mathrm{l}$ was injected into the HPLC. One hundred twenty fractions (1 ml each) were collected at a flow rate of $1.0 \mathrm{ml} /$ min for progestagens and 80 fractions were collected at 0.3 $\mathrm{ml} / \mathrm{min}$ for estrogens. Each fraction was extracted with diethyl ether, and immunoreactivity was determined by the EIA with progesterone, estradiol-17 $\beta$ and estrone antisera. Fecal steroid metabolites were identified by comparing the immunoreactive fraction numbers with reference tracers [13]. As reference tracers, progesterone, $5 \alpha$-pregnan-3,20-dione, $5 \alpha$-pregnan-3 $\alpha$-ol-20-one, $5 \alpha$-pregnan-3 $\beta$-ol-20-one, $5 \beta$-pregnan- $3 \alpha$ -ol-20-one and $5 \beta$-pregnan-3 $\beta$-ol-20-one were used for progestagens analysis, and estradiol-17 $\beta$, estradiol-17 $\alpha$ and estrone were used for estrogens analysis.

\section{Data analysis}

All the steroid hormone values in feces were expressed as the content per one gram of dried feces. Data are presented as the mean \pm standard deviation (SD). Ovarian cycle length, gestation period and postpartum estrus were based on fecal progestagen concentrations.

The beginning of corpus luteum formation was determined using an iterative process described by North and Harder [14]. Briefly, the mean progestagen concentrations of all nonpregnancy period samples from a female Somali wild ass were calculated, and values greater than the mean $+1.75 \mathrm{SD}$ 
were considered high progestagen values. High progestagen values were then removed from the dataset, and the average was recalculated. This process was repeated until no values exceeded the mean +1.75 SD. A $4.03 \mu \mathrm{g} / \mathrm{g}$ (mean +1.75 SD) concentration of the remaining sample progestagen values was designated as the baseline, and values above this baseline were considered to be the luteal phase.

The estrous cycle was calculated as the interval between the fecal sampling day just before the beginning of one luteal phase and the fecal sampling day just before the beginning of the following luteal phase. Mounting behaviors were frequently observed in this study, but successful copulation was hardly seen. Therefore, the gestation period was defined from the fecal sampling day just before the beginning of the luteal phase (estimated conception) to stillbirth. The number of days until postpartum estrus was calculated using the fecal sampling day just before the beginning of the first luteal phase after giving birth.

\section{RESULTS}

\section{Profiles of fecal steroid hormone metabolites during the ovarian cycle and the pregnancy}

The changes in the fecal concentration of progestagens and estrogens are shown in Fig. 1 In Fig. 1a, the pattern of the progestagen concentrations exhibited five ovarian cycles from the first parturition (death just after birth) to the next pregnancy. In the following 67 days, progestagen concentrations maintained an average value of $8.9 \mu \mathrm{g} /$ g (FEP). Progestagen concentrations increased gradually to approximately 5-fold, and then maintained this value for about 200 days. Progestagens increased markedly up to approximately 18-fold before stillbirth, and then declined sharply afterward.

Due to the changes of progestagen concentration, it was calculated that an average $( \pm S D)$ ovarian cycle is $22.7 \pm$ 2.9 days (range: 21 to 28 days, 6 cycles), and the estimated gestation period is 390 days. Cyclic progestagen patterns recovered in 30 days and 45 days after first (death just after birth) and second (stillbirth) parturition, respectively (Fig. 1a).

In Fig. 1b, the estrogen concentrations did not show cyclic changes like those of progestagens during ovarian cycles. The results showed that estrogens in pregnancy increased markedly from day 95 after estimated conception (based on the progestagen profile), reached a peak in the middle of pregnancy, and then gradually decreased until approaching stillbirth. The first pregnancy peak value of $E_{1}$ (approximately $3 \mu \mathrm{g} / \mathrm{g}$ ) was only half that of the second pregnancy (stillbirth, $6 \mu \mathrm{g} / \mathrm{g})$.

\section{Fecal steroid hormone metabolites}

The immunoreactive progesterone concentrations in HPLC fractions of extracted fecal samples in the four stages of the second pregnancy (FEP, SEP, MP, LP) of a female Somali wild ass are shown in Fig. 2a. The major immunoreactive peaks of No.76-78 and No.106-108 were consistent with $5 \alpha$ -pregnan-3 $\beta$-ol-20-one and $5 \alpha$-pregnan-3,20-dione reference tracers, respectively. The small immunoreactive peak No.13 could not be identified. There were no distinct differences in the components of progestagens among the four stages of pregnancy.

Figure $2 \mathrm{~b}$ and $2 \mathrm{c}$ show the three corresponding stages of pregnancy (EP, MP, LP) according to the immunoreactive estradiol-17 $\beta$ and estrone concentrations. For immunoreactive estradiol-17 $\beta$, a marked immunoreactive peak and a small peak were observed in No. 30-32 and No. 45-48, respectively. For immunoreactive estrone, two small immunoreactive peaks and one marked peak were observed in No.30-32, No.34-36 and No.45-47, respectively. These peaks were consistent with estradiol-17 $\beta$ (No.30-33), estradiol-17 $\alpha$ (No.34-36) and estrone (No.45-48) tracers, and showed a high value in midpregnancy. The components of estrogens were the same as those during the three stages of pregnancy.

\section{DISCUSSION}

This study describes for the first time the endocrine pattern based on fecal progestagen and estrogen metabolites during the ovarian cycle and pregnancy in a female Somali wild ass. The components of fecal progestagen and estrogen metabolites were also clarified in the different stages of pregnancy.

It has been reported that measuring fecal progestagens can be used for monitoring the estrous cycle in the domestic horse [15-17], Przewalski's horse [10] and Grevy's zebra [11]. In our study, the change in fecal progestagens showed ovarian cyclicity and was an average of $22.7 \pm 2.9$ days (range: 21 to 28 days) per cycle. This result is similar to the estrous cycle reported in Somali wild ass, with a common range from 25 to 28 days [18].

Our results showed that the estimated gestation period based on changes in fecal progestagens was approximately 


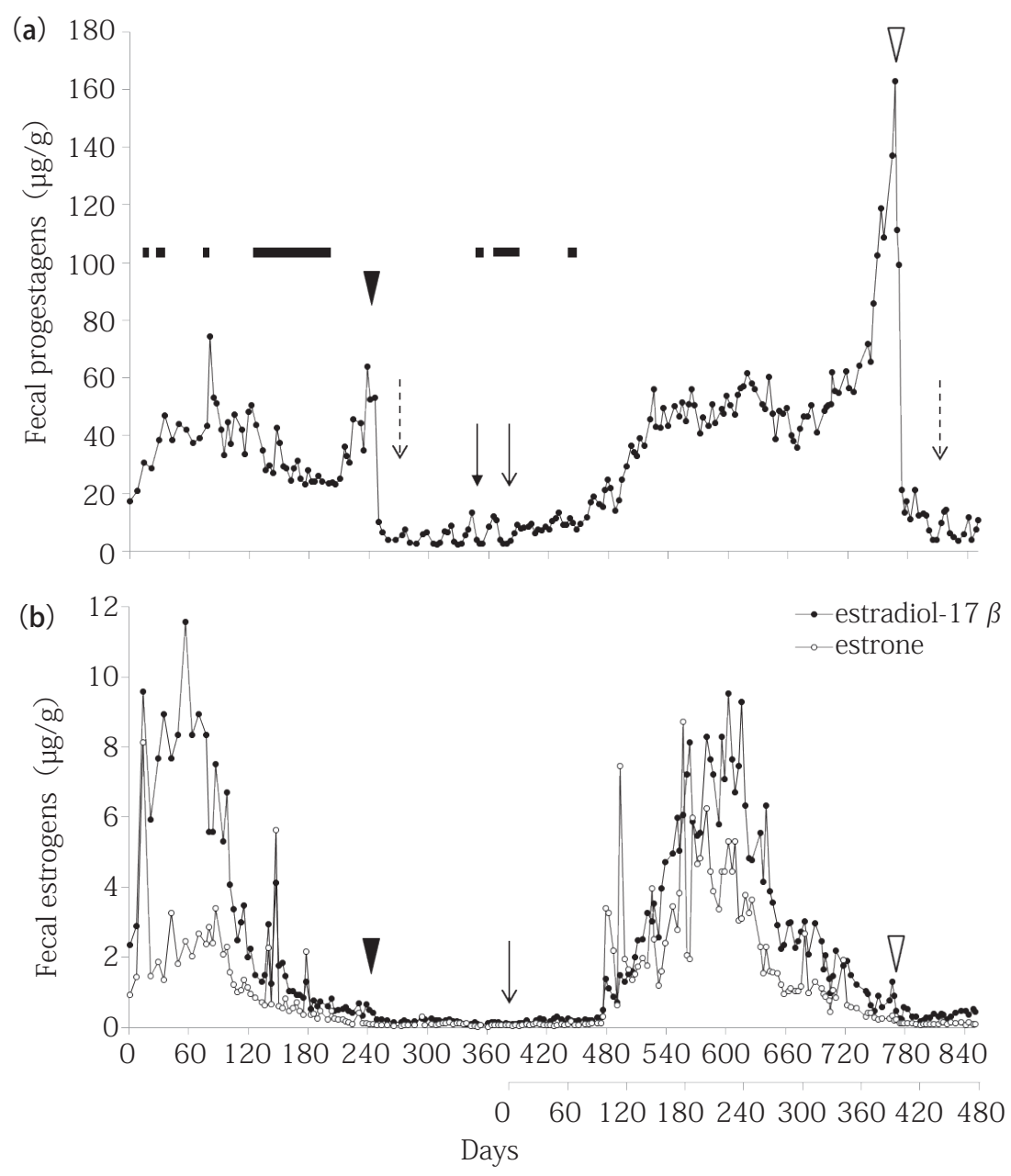

Fig. 1 Profiles of fecal progestagens (a) and estrogens (b) during ovarian cycles and two pregnancies in a female Somali wild ass. $\mathbf{\square}$ : period when mounting behavior was observed. $\mathbf{v}$ : day of first parturition (death just after birth). $\downarrow$ : day of copulation. $\downarrow$ : estimated conception (based on progestagen profile). $\nabla$ : day of second parturition (stillbirth). $\downarrow$ : postpartum estrus (based on progestagen profile). The X-axis is the days from starting this study (upper) and from second conception (lower).

390 days, within the range of 377 to 404 days reported in the Somali wild ass [19]. In the gestation period, progestagen levels varied in different stages, with an average value of 8.9 $\mu \mathrm{g} / \mathrm{g}$ during the first half of early pregnancy, and then sharply increasing from 67 days and 347 days after the estimated conception. A similar overall pattern of plasma $5 \alpha$-pregnanes can be found in domestic mares, and this value increased gradually after about 60 days of pregnancy until a more rapid increase was observed 30 days prepartum [20, 21]. According to these results, the assay of fecal progestagens is an effective method for monitoring the ovarian cycle (probably ovulatory cycle) and pregnancy.
Based on the profile of fecal progestagens, it was speculated that postpartum ovarian cycle occurred 30 and 45 days after the first (death just after birth) and second (stillbirth) parturition, respectively, since the ass never had a normal parturition during this study. The number of days until normal postpartum ovarian cycle was not identified in this study. A female Somali wild ass was reported to be in estrus again one to two weeks after parturition [22].

Fecal unconjugated estrogens showed no distinct changes during the ovarian cycle in the present study. However, the plasma estrogen levels of domestic mares increase during estrus, and thus the ovarian follicles produce estrogens [23, 

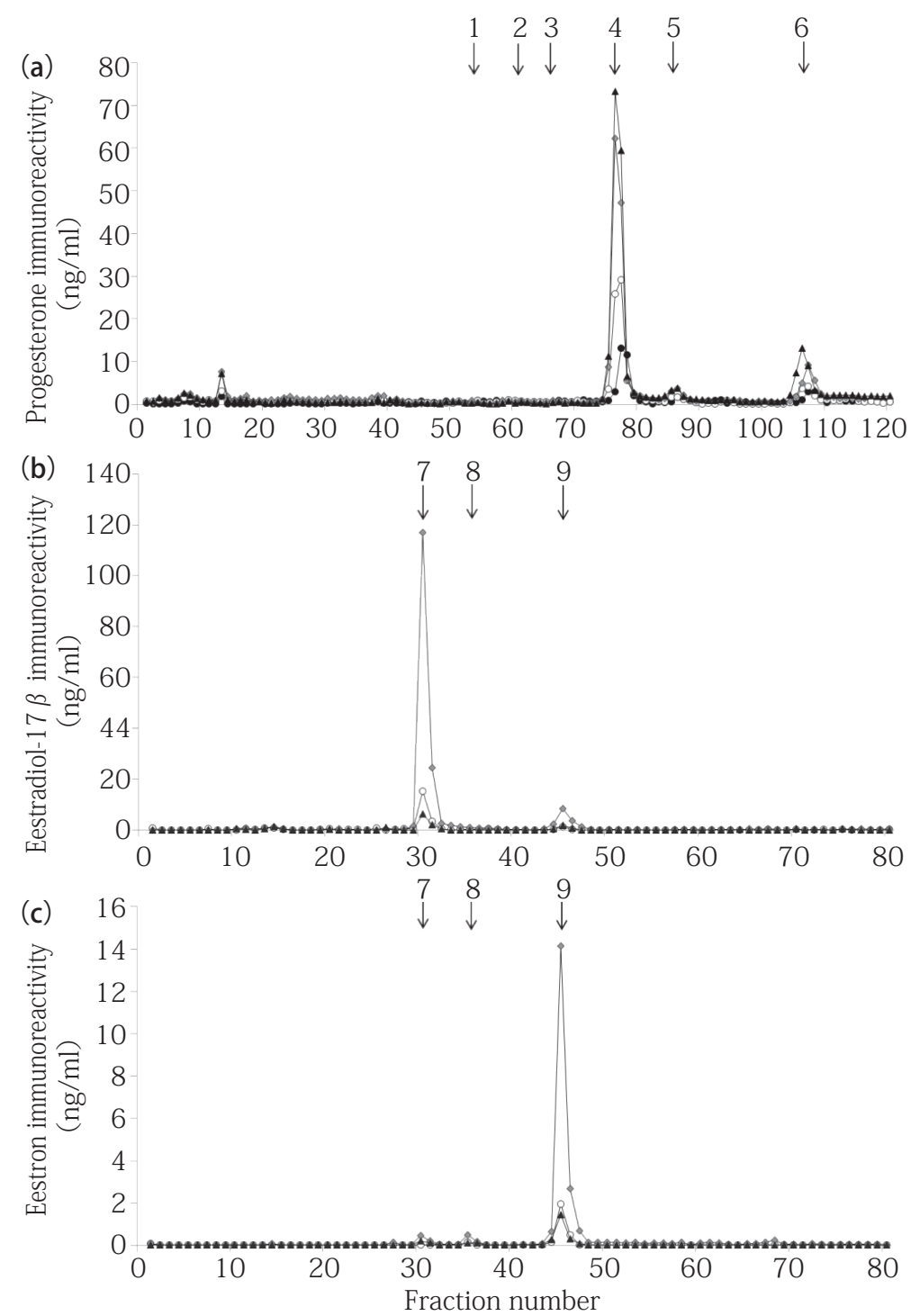

Fig. 2 Immunoreactive progesterone (a), estradiol-17 $\beta$ (b) and estrone (c) immunoreactivity in HPLC fractions of extracted fecal samples during early, mid- and late pregnancy from a female Somali wild ass. (a): first half $(\bullet)$, second half $(\odot)$ of early pregnancy, mid- pregnancy $(\bullet)$ and late pregnancy $(\boldsymbol{\Delta})$. (b) and (c): early $(\circ)$, mid- $(\diamond)$ and late pregnancies $(\boldsymbol{\Delta})$. Immunoreactive peaks were compared to the reference tracer as follows: 1: progesterone, 2: $5 \beta$-pregnan-3 $\alpha$-ol-20-one, 3: $5 \beta$-pregnan-3 $\beta$-ol-20-one, 4: $5 \alpha$ -pregnan-3 $\beta$-ol-20-one, 5: $5 \alpha$-pregnan-3 $\alpha$-ol-20-one, 6: $5 \alpha$-pregnan-3,20-dione, 7: estradiol-17 $\beta$, 8: estradiol-17 $\alpha$, 9: estrone.

24]. It has been also reported that fecal estrogen (estrone conjugates and $\mathrm{E}_{2}$ ) analysis by high-frequency (every day) fecal sampling could monitor the ovarian function in non-pregnant domestic mares $[15,16]$. However, intravenously infused ${ }^{14} \mathrm{C}$ $\mathrm{E}_{1}$ during the estrous period of ponies was excreted via feces at only $2 \%$, and mainly excreted via urine [9]. It seems that highfrequency fecal sampling and analysis of urinary estrogens is necessary for noninvasive monitoring of ovarian follicular activity in wild asses.

In mid- and late pregnancy, estrogens have been reportedly produced by the fetoplacental unit and a high concentration of estrogens is detectable in both the blood and feces of the mare [25-27]. The fecal estrogens peak in mid-pregnancy showed a value approximately 50 times that in non-pregnancy in Somali 
wild ass, and the change pattern was found to be similar to domestic mares in our study (second pregnancy). This result suggests that the Somali wild ass and domestic mares may share similar endocrine characteristics in pregnancy. Therefore, fecal estrogen analysis can be used for monitoring the endocrine function of the fetoplacental unit in the Somali wild ass.

Two parturitions were observed during our study period. The foal in the first pregnancy died just after parturition (breathing trace of the lung was confirmed by hydrostatic lung test), and the second was stillborn (breathing trace of the lung was not confirmed). The two foals weight [27.65kg (first) and $31.00 \mathrm{~kg}$ (second)] were within the range from 25 to $32 \mathrm{~kg}$ reported by Basel Zoo (Switzerland) [19]. The cause of stillbirth (second parturition) was not clear in this study. The profile of fecal progestagens was similar to the profile during the normal gestation period in domestic and Przewalski's mares (Muren, unpublished data). In domestic mares in mid- and late pregnancy, progestagens and estrogens were produced by the fetoplacental unit [21, 25-27]. In our study a sharp increase in the first pregnancy was not observed in late pregnancy, and $E_{1}$ was only half that of the stillbirth. These different conditions might be due to endocrine dysfunction of the fetoplacental unit.

In our study, the assay of fecal progestagens was an effective method for monitoring the ovarian cycle. It has been reported that non-metabolized progesterone was barely present, but 5 $\alpha$-pregnane-3 $\beta$-ol-20-one and $5 \alpha$-pregnan-3,20-dione were found in the feces of non-pregnant ponies [17]. In our study, 5 $\alpha$-pregnane-3 $\beta$-ol-20-one and $5 \alpha$-pregnan-3,20-dione were present in the feces during pregnancy. These results suggest that at least $5 \alpha$-pregnane-3 $\beta$-ol-20-one and $5 \alpha$-pregnan3,20-dione were excreted as metabolites of progesterone into the feces from the blood circulation in Somali wild ass.

Plasma $5 \alpha$-pregnane- $3 \beta$-ol-20-one and $5 \alpha$-pregnan-3,20dione were detectable and showed a parallel increase during early pregnancy in ponies, and their high value was maintained until parturition [20]. In the present study, it was confirmed that $5 \alpha$-pregnane-3 $\beta$-ol-20-one and $5 \alpha$-pregnan-3,20-dione were present in feces throughout pregnancy, and increased as it progressed. Fecal $5 \alpha$-pregnane- $3 \beta$-ol-20-one and 5 $\alpha$-pregnan-3, 20-dione are good indicators for monitoring pregnancy in Somali wild ass.

Unconjugated compound estrogens were excreted into the feces of mares, such as $E_{2}, E_{1}$ and estradiol-17 $\alpha$ [26, 28, 29]. It has been reported that the change in fecal unconjugated estrogens was similar to that in blood; estrogens are produced by the fetoplacental unit in mid- and late pregnancy in mares $[25,26]$. In our study, unconjugated $\mathrm{E}_{2}, \mathrm{E}_{1}$ and estradiol-17 $\alpha$ were also detected in feces during pregnancy. These results suggest that the analysis of total unconjugated estrogens in feces is effective for assessing fetoplacental function in Somali wild ass.

In conclusion, the change pattern of fecal $5 \alpha$-pregnane- 3 $\beta$-ol-20-one and $5 \alpha$-pregnan-3,20-dione is effective for monitoring the ovarian cycle and pregnancy. The profiles of fecal $E_{2}$ and $E_{1}$ reflect the endocrine function of the fetoplacental unit. Continuous noninvasive monitoring should be widely performed to further understand the reproductive physiology and promote propagation programs in the female Somali wild ass.

\section{REFERENCES}

1. Moehlman PD. 2002. Status and action plan for the African wild ass. In Equids: Zebras, Asses and Horses, Status Survey and Conservation Action Plan (Moehlman PD ed), pp. 2-9. IUCN. Gland, Switzerland.

2. IUCN. 2013. The IUCN Red List of Threatened Species. Available from http://www.iucnredlist.org/details/7949/0. Downloaded on 11 November 2013

3. Pohle C. 2013. International Studbook of the African Wild Asses. Tierpark Berlin, Berlin, Germany.

4. Henry M, Figueiredo AE, Palhares MS, Coryn M. 1987. Clinical and endocrine aspects of the oestrous cycle in donkeys (Equus asinus). J Reprod Fertil Suppl 35: 297-303.

5. Meira C, Ferreira JCP, Papa FO, Henry M. 1998. Ovarian activity and plasma concentrations of progesterone and estradiol during pregnancy in jennies. Theriogenology 49: 1465-1473.

6. Lemma A, Schwartz HJ, Bekana M. 2006. Application of ultrasonography in the study of the reproductive system of tropical jennies (Equus asinus). Trop Anim Health Prod 38: 267 274.

7. Taberner E. Medrano A, Peña A, Rigau T, Miró J. 2008. Oestrus cycle characteristics and prediction of ovulation in Catalonian jennies. Theriogenology 70: 1489-1497.

8. Schwarzenberger F. 2007. The many uses of non-invasive faecal steroid monitoring in zoo and wildlife species. Int Zoo Yb 41: 5274 .

9. Palme R, Fischer P, Schildorfer H, Ismail MN. 1996. Excretion of infused ${ }^{14} \mathrm{C}$-steroid hormones faeces and urine in domestic livestock. Anim Reprod Sci 43: 43-63.

10. Schwarzenberger F, Möstl E, Bamberg E, Hegel G. 1992. 
Monitoring of corpus luteum function by measuring progestagens in faeces of non-pregnant mares (Equus caballus) and Przewalski mares (Equus przewalskii). Anim Reprod Sci 29: 263-273.

11. Asa CS, Bauman JE, Houston EW, Fischer MT, Read B, Brownfield CM, Roser JF. 2001. Patternsof excretion of fecal estradiol and progesterone and urinary chorionic gonadotropin in Grevy's zebras (Equus grevyi): Ovulatory cycles and pregnancy. Zoo Biol 20: 185-195.

12. Kusuda S. Morikaku K. Kawada K. Ishiwada.K. Doi O. 2007. Excretion patterns of fecal progesterone, Androgen and estrogen during pregnancy, parturition and postpartum in okapi (Okapia johnstoni). J Reprod Dev 53: 143-150.

13. Adachi I, Kusuda S, Nagao E, Taira Y, Asano M, Tsubota T, Doi O. 2010. Fecal steroid metabolites and reproductive monitoring in a female Tsushima leopard cat (Prionailurus bengalensis euptilurus). Theriogenology 74: 1499-1503.

14. North LA, Harder JD. 2008. Characterization of the estrous cycle and assessment of reproductive status in Matschie's tree kangaroo (Dendrolagus matschiei) with fecal progestin profiles. Gen Comp Endocrinol 156: 173-180.

15. Barkhuff V, Carpenter B, Kirkpatrick JF. 1993. Estrous cycle of themare evaluated by fecal steroid metabolites. J Equine Vet Sci 13: 80-83.

16. Amer HA, Shawki G, Ismail R. 2008. Profile of steroid hormones during oestrus and early pregnancy in Arabian mares. Slov Vet Res 45: 25-32.

17. Palme R, Möstl E, Brem G, Schellander K, Bamberg E. 1997. Faecal metabolites of infused ${ }^{14} \mathrm{C}$-progesterone in domestic livestock. Reprod Dom Anim 32: 199-206.

18. Epstein H. 1984. Ass, Mule and Onager. In Evolution of Domesticated Animals (Mason IL eds), pp. 174-184. Longman, London.

19. Pagan O. Von Houwald F, Wenker C, Steck BL. 2009. Husbandry and breeding of Somali wild ass Equus africanus somalicus at
Basel Zoo, Switzerland. Int Zoo Yb 43: 198-211.

20. Holtan DW, Houghton E, Silver M, Fowden AL, Ousey J, Rossdale PD. 1991. Plasma progestagens in the mare, fetus and newborn foal. J Reprod Fertil 44: 517-528.

21. Ginther OJ. 1993. Endocrinology of pregnancy. In Reproductive Biology of the Mare Basic and Applied Aspects 2nd (Ginther OJ ed), pp. 419-456. Equiservices, Cross plains.

22. Moehlman PD. 2005. Endangered wild equids. Sci Am 293: 86-93.

23. Mienecke B, Gips H, Meinecke-Tillmann S. 1987. Progestagen, androgen and oestrogen levels in plasma and ovarian follicular fluid during oestrous cycle of the mare. Anim Reprod Sci 12: 255265.

24. Ginther OJ, Utt MD, Beg MA. 2007. Follicle deviation and diurnal variation in circulating hormone concentrations in mares. Anim Reprod Sci 100: 197-203.

25. Schwarzenberger F, Möstl E, Bamberg E, Pammer J, Schmehlik O. 1991. Concentrations of progestagens and oestrogens in the faeces of pregnant Lipizzan, trotter and thoroughbred mares. $J$ Reprod Fertil 44: 489-499.

26. Janowski T, Skolimowska A, Zdunczyk S, Baranski W. 2008. Ostrogens in faeces as an indicator of the foeto-placental unit function in mares. Exp Clin Endocr Dlab 116: 404-408.

27. Ousey JC. 2011 . Endocrinology of pregnancy. In: Equine Reproduction 2nd (Mckinnon AO, Squires EL, Vaala WE, Varner DD eds), pp. 2222-2233. John Wiley \& Sons, West Sussex.

28. Bamberg E, Choi HS, Möstl E, Wurm W, Lorin D, Arbeiter K. 1984. Enzymatic determination of unconjugated oestrogens in faeces for pregnancy diagnosis in mares. Equ Vet J 16: 537-539.

29. Schwarzenberger F, Möstl E, Palme R, Bamberg E. 1996. Faecal steroid analysis for non-invasive monitoring of reproductive status in farm, wild and zoo animals. Anim Reprod Sci 42: 515-526. 
ソマリノロバにおける穓中の性ステロイドホルモン代謝物の同定とその排泄パターンからみた卵巣周期と妊娠 木仁 ${ }^{1)}$, 楠田哲士 ${ }^{1,2}$, 柴田枝梨 ${ }^{3)}$, 土井 守 ${ }^{1,2)}$

1) 岐皁大学大学院連合農学研究科 ₹ 501-1193 岐阜県岐阜市柳戸 1-1

2) 岐阜大学応用生物科学部７501-1193 岐阜県岐阜市柳戸 1-1

3）横浜市立金沢動物園＝236-0042 神奈川県横浜市金沢区釜利谷東 5-15-1

[2013 年 12 月 30 日受領, 2014 年 4 月 22 日採択 $]$

要 約

雌ソマリノロバの生殖状態を非侵襲的にモニタリングする内分泌学的手法の確立を目的とした。プロジェステロン $\left(\mathrm{P}_{4}\right)$, エス トラジオール - $17 \beta \quad\left(\mathrm{E}_{2}\right)$ 扔よびエストロン $\left(\mathrm{E}_{1}\right)$ 抗体を用いた酵素免疫測定（EIA）法により賴中のプロジェスタージェンとエス トロジェンを測定した。また，高速液体クロマトグラフィー（HPLC）とEIA 法を併用し，妊娠の各ステージの糞中に排泄される これらの性ステロイドホルモン代謝物の同定を行った。非妊娠期のソマリノロバの糞中プロジェスタージェン含量の変化は卵巣周 期を示したが，エストロジェンでは周期的な変動が認められなかった。翼中のプロジェスタージェン含量の動態から算出した卵巣 周期（土SD）は22.2 2.9 日間であった。妊娠期を通して翼中プロジェスタージェン含量が変化し，特に妊娠 67 日と 347 日に 2 回の急激な増加が認められ，出産（死産）の直前にピーク值を示した。この動態によって算出した妊娠期間は 390 日間であった。 翼中エストロジェン含量は妊娠 95 日から急激な増加を開始し, 妊娠中期にピークが認められ，その後出産（死産）までに徐々に 減少した。妊娠各ステージの翼中から主に $5 \alpha$-pregnane-3 $\beta$-ol-20-one, $5 \alpha$-pregnan-3,20-dione， $\mathrm{E}_{2}$ および $\mathrm{E}_{1}$ が検出された。こ れらのことから，翼中 $5 \alpha$-pregnane-3 $\beta$-ol-20-one または $5 \alpha$-pregnan-3,20-dione の測定は, 卵巣周期と妊娠期のモニタリングに 有用であり, 糞中 $\mathrm{E}_{2}$ または $\mathrm{E}_{1}$ の測定は, 胎盤内分泌能を捉えるのに有用であると考えられた。

キーワード : 発情周期, 穓中ホルモン, プロジェステロン, 妊娠, ソマリノロバ

一日本野生動物医学会誌 19(2)：49-56, 2014 